International Research Journal of Management, IT \& Social Sciences
Available online at https://sloap.org/journals/index.php/irjmis/
Vol. 5 No. 4, July 2018, pages: 26 45
ISSN: 2395-7492
https://doi.org/10.21744/irjmis.v5n4.253

\title{
Effect of Six Sigma on Performance of Medium Scale Manufacturing Firms in South-Eastern Nigeria
}

\author{
Okafor Ikechukwu Godwin ${ }^{a}$ \\ Kalu Emmanuel Agbaeze ${ }^{b}$ \\ Geoffrey Owoicho Ekoja ${ }^{c}$ \\ Joseph Obamen ${ }^{\mathrm{d}}$
}

Article history:

Received: 20 February 2018

Revised: 25 June 2018

Approved: 1 July 2018

Published: 3 July 2018

Keywords:

Six Sigma;

Performance;

Manufacturing firms;

South-Eastern Nigeria;

\begin{abstract}
The effect of Six Sigma on Performance of MSF's in South-East Nigeria. The main objective is to determine the effects of Six Sigma on the performance of MSF's in South-East, Nigeria. While others are to: determine the extent at which process defines influence the customers' patronage of their product, determine the extent at which process measurement influences product positioning and determine the extent at which improvement on production processes influence customers retention. The result shows that process definition practice among MSF's significantly influenced customers' patronage, process measurement among MSF's was found significant influencing positioning and production improvement significantly influenced customer retention among MSF's in South-East Nigeria. The study concluded adoption of Six Sigma practices positively influences the performance of the MSF's in South-East Nigeria.
\end{abstract}

2395-7492@ Copyright 2018. The Author. This is an open-access article under the CC BY-SA license (https://creativecommons.org/licenses/by-sa/4.0/) All rights reserved.

\section{Author correspondence: \\ Okafor Ikechukwu GODWIN, \\ Doctorate Candidate, Department of Management, Faculty of Business Administration, \\ University of Nigeria Enugu Campus, Enugu State Nigeria. \\ Email address: ekojageoffrey2014@gmail.com or geoffrey.ekoja.pg83344@unn.edu.ng}

\section{Introduction}

In the last $20^{\text {th }}$ century, Six Sigma has become one of the most successful improvement models for business across the globe. In most case, six sigma model is being considered as a science meant for business strategy of blending the firm into the society, without or with little compromising. The earlier implementation of Six Sigma was in a manufacturing firm, to make the firm produce the exact customers' requirement in terms of products, quality and quantity with minimal possible waste on the part of a manufacturing firm. Interestingly, in today's business world, Six Sigma has been successfully applied in finance, healthcare, banking and many other business processes (Natarajan and

${ }^{a}$ Department of Management, Faculty of Business Administration, University of Nigeria Enugu Campus, Enugu State Nigeria

${ }^{\mathrm{b}}$ Department of Management, Faculty of Business Administration, University of Nigeria Enugu Campus, Enugu State Nigeria

${ }^{c}$ Department of Management, Faculty of Business Administration, University of Nigeria Enugu Campus, Enugu State Nigeria

${ }^{\mathrm{d}}$ Department of Management, Faculty of Business Administration, University of Nigeria Enugu Campus, Enugu State Nigeria 
Morse, 2009). In spite of wider range of application of Six Sigma, evidence from studies such as (Obaidullah, 2005, Reddy \& Reddy, 2010 and Moosaa \& Sajid, 2010) has shown that most firms are not fully implementing Six Sigma, while most are partner other techniques such as TQM and SMPs with Six Sigma as a result, the desired outcome is falling below expectation. Evidence from studies on the performance of manufacturing firms in most African countries manufacturing firms have shown that the adoption of Six Sigma has been in practice for more than two decades, Alexander, Jacqueline and Jacqueline (2015) argued that most firms in Eastern part of Africa shifted from TQM to Six Sigma after identified the performance of six sigma firms in the advanced countries. Likewise, Ignatio and Charles (2015) indicated that most firms in South Africa adopt Six Sigma just after foreign firms in various parts of South Africa are noticeable performing better and recording better patronage among local consumers. The scenario of Six Sigma is not strange in the manufacturing firms in Nigeria. Enoch (2013) expressed that most small and medium scale enterprises located in the Lagos, Kano, Port-Harcourt, and another major city in Nigeria. Are among the first leading firms integrated Six Sigma in their processing method in Nigeria. Most medium scale manufacturing firms in Nigeria are continually making efforts to maximize the wealth of their financiers as well as profiting the economic welfare of their shareholders. Thus, efforts to improve their performance in tune of their desire economic benefits led to the adoption of known production strategies such as Six Sigma process to turn things around in terms of product acceptance, product patronage, product recognition, product positioning as well as overall firm performance. However, due to the complexity of the business environment as well as the availability of various tested production strategies, it may be somewhat hard to single out Six Sigma strategy as performing strategy among other production strategies available for the manufacturing firms for effective performance. South-Eastern Nigeria is one of the regions where manufacturing and production activities are on-going at a high rate. The region is known for its renowned economic activities, which make the competition among firm very stiff and uncompromised. Thus, each manufacturing firm in the region is struggling to beat off the competitors with modern production strategies, such as Six Sigma process aimed at improving their production processes, human resource management, and environmental consideration.

\section{Statement of the Problem}

Low profitability among medium scale enterprises in Nigeria has been linked with poor human resource management, the cut-off between firm and customers, the persistent use of outdated technologies, lack of performance evaluation and inconsistent production assessment as well as inability to apply modern management techniques (Onwughalu, Okeke and Henry-Chibor 2017:5).

Earlier studies in the field of business management and organisation processing have identified the importance of adoption of Six Sigma practices to ensure the effective management, smooth processing, minimal defects, as well as effective customer-business relationship, which most firms in advanced nations are using to edge their competitors, controlling the market and building corporate images. However, the study by Umude-Igbruand Brian (2015) indicated that level of persistent failure in the Nigeria medium scale manufacturing firms to meet their annual target and impress patronage within and outside Nigeria has raised the question of how effective is the adoption of Six Sigma practices in the Nigerian manufacturing firms on their products, employee performance, customers' relation as well as general human resources management.

South-Eastern Nigeria is among the few regions where industrial activities are prominent. However, the competition among these manufacturing firms to attract more customers within and outside the region has led many to the adoption of Six Sigma technique by the majority of these firms, to ease their production process and well positions their brand. However, it is hard to notice among these numerous manufacturing firms those that adopt the six sigma and those that stick with other methods such as ISO 9001 in terms of performance, market gain and business growth. Therefore, this study is set-out to determine the effect of Six Sigma on the performance of medium scale manufacturing firms in south-eastern Nigeria.

\section{Objectives of the Study}

The broad objectives of this study are to determine the effects of Six Sigma on the performance of medium scale manufacturing firms in the south-eastern part of Nigeria. The specific objectives are to:

a) Determine the extent to which the process define influences the customer's patronage of the product of the medium scale manufacturing firm in South-Eastern Nigeria.

b) Identify the extent to which the process measurement influences product positioning for medium scale manufacturing firms in south-eastern Nigeria.

Okafor, G., Agbaeze, E., Ekoja, G., \& Obamen, J. (2018). Effect of six sigma on performance of medium scale manufacturing firms in south-eastern Nigeria. International Research Journal of Management,

IT and Social Sciences, 5(4), 26-45. https://doi.org/10.21744/irjmis.v5n4.253 
c) Ascertain the extent to which the improvement on production processes influences customers retention among the medium scale manufacturing firms in south-eastern Nigeria

\section{Research Methods}

The study adopted survey research design. The population for this study involves the total of 200 manufacturing firms located in the five states in South-Eastern part of Nigeria. However, the targeted population comprised of all 421 employees in the 5 participating firms selected at one-per state rate, across the 5 states from South-Eastern part of Nigeria. The sample size for this study is determined using Krejcie and Morgan (1970) sample size, which the formula is given as follow:

$$
\text { Size }=\frac{X^{2} N P(1-p)}{d^{2}(N-1)+X^{2} P(1-P)}
$$

Where $\mathrm{x}^{2}=$ confidence level (3.84 at 0.05 significant value), $\mathrm{N}=$ population size $(421)$

$\mathrm{P}=$ population proportion $(0.50)$.

$\mathrm{d}=$ degree of accuracy $(0.05)$.

Therefore, $=\frac{3.84 * 421 * 0.5(1-0.5)}{0.05^{2}(421-1)+X^{2} 0.5(1-0.5)}$

$$
\mathrm{n}=201
$$

Therefore, the sample size for this study is 201 employees of the five manufacturing firms selected across the southeastern states of Nigeria. The simple random sampling technique was later used, to select the proportion of employees from each of the participating manufacturing firm. Therefore, 46 employees were randomly sampled from a total of 94 employees found PGN Ltd in Abia State. Likewise, 34 employees were sampled from 70 staff of AGES Industries Ltd in Anambra state. Also, 37 employees were sampled from 75 staff of Aluminum Manufacturing Co. Nig. Ltd. in Ebonyi state, while, 53 employees were sampled from 108 staff of Anambra Motor Manufacturing Co (ANAMMCO) Ltd of Enugu state and 36 employees were sampled from total 74 workers in Aluminum Extrusion industry Plc in Imo state respectively. The study used structured questionnaire, designed on 5 points Likert scale of Strongly Agreed, Agreed, Disagreed, Strongly Disagreed and Undecided. The questionnaire was sectioned into three, the first section focused on respondents Bio-data information while the second section contained items probing responses on in line with the objectives of the study and the third section is a general level questions. The data obtained from total 187 duly filled and returned questionnaires were analyzed using frequency count, simple percentage, and weighted average while data on hypotheses were analyzed using Pearson Product Moment Correlation (PPMC) at 5\% confidence level.

\section{Research Hypotheses}

The below research hypothesis is put forward to solicit answers to the objectives of the study as thus:

a) There is a significant relationship between the level of process definition and customers' patronage of the products of medium scale manufacturing firms in south-eastern Nigeria

b) There is a significant relationship between the level of process measure and positioning of products of medium scale manufacturing firms in South-eastern Nigeria

c) There is a significant relationship between the level of productivity improvement strategy and level of customers' retention among the medium scale manufacturing firms in south-eastern Nigeria. 
Conceptual Framework

\section{The Concept of Six Sigma}

The initiator of Six Sigma concepts can be traced to Motorola in the 1980s, before being enhanced in the late 1990s by the likes of General Electric and Allied Signal. The initial Six Sigma process by Motorola was developed and introduced into the practices of manufacturing firm before late intervention by the General Electric, Allied Signal and others in 1990 led to the adoption of Six Sigma outside manufacturing firms, such as financial institution, health institution, marketing and others non-manufacturing area of the company. Dahlgaard-Park and Dahlgaard (2006) argue that Six Sigma be adapted into another field of businesses, especially non-manufacturing firms, after the initial success recorded in the manufacturing firms through the introduction of Six Sigma. In today's' business, Six Sigma has become one of the primary quality initiatives, serving as a critical business tool for the 21 st century. Most firms in the fastchanging and competitive business environments have been noticeably used Six Sigma initiatives to gain improvements in their process and product quality and to gain competitive advantage. The breakthrough achievements recorded by the manufacturing and non-manufacturing firms through Six Sigma could be attributed to the model's strategy of directly improving the customers' satisfaction ratings as well as ensuring the bottom line savings.

Varzandeh and Kamy (2010) assert that Six Sigma can be defined as a methodology of combining various quality elements in any organization setting, to create a chain of supply from firms to environment (consumers). Also, Tahir (2010) expresses that the Six Sigma method is a response to the needs of the consumers. That is, in adopting Six Sigma, the comments from customers serve as the main key to achieve quality process. Radhakrishnan and Sivakumaran (2010) expressed Six Sigma as an appropriate tool for converting various management problems into statistical compliant problems and to find an appropriate statistical solution before revert it back to a management solution. This shows that six sigma processes are based on facts and figures, thereby guiding the management in the firms to take right business decisions at the right time. Mandahawi, Al-Shihabi, Abdallah, and Alfarah (2010) expresses that "Six Sigma system is essentially used to develop the performance of an existing process and reduce its variation to reach the final goal which is the customer satisfaction." In the view of Pokharkar, Jadhav, Gholve, and Vilasrao (2010), the Six Sigma covered three main processes, which are improvement, design, and redesign as well as effective process management. Dileep and Rau (2010) expresses that the "Six Sigma is about results, increasing profitability through improved quality and efficiency, this desired results accomplished through the use of two Six Sigma methodologies: DMAIC (Define, Measure, Analyze, Improve, Control) and DMADV (Define, Measure, Analyze, Design, Verify)". Schroeder Linderman, Liedtke and Choo (2008) argue that most organizations and business are likely to find various benefits from the adoption of Six Sigma approach due to its suitability to meet the requirements of many firms.

\section{Phases of Six Sigma Method}

Dileep and Rau (2010) express that the "Six Sigma is about increasing profitability through improved quality and efficiency. Thus, in order to achieve the desired results, the Six Sigma used two methodologies: DMAIC (Define, Measure, Analyze, Improve, Control) and DMADV (Define, Measure, Analyze, Design, Verify). Dileep and Rau (2010) express further that DMAIC process is an improvement system for existing processes falling below specification and looking for incremental improvement, while DMADV process serves as an improvement system used to develop new processes or products at Six Sigma quality levels. Likewise, DMADV may be employed if a current process in an organization requires more than just incremental improvement. The detail of six sigma process is given in Figure 1.

a) Define Phase

The Define Phase is the first phase of the Six Sigma improvement process. In this phase, the project team creates a Project Charter, a high-level map of the process and begins to understand the needs of the customers of the process. This is a critical phase in which the team outlines the project focus for themselves and the leadership of the organization. At this phase, the problems concerning; who the customers are and what the customers want, were expected to be defined. The top management role at this stage includes determining at what quality and quantity their product will satisfy the consumers. Such a process definition leads to defect reduction since the firm can choose a Critical to Quality (CTQ) measure due to the earlier identification of target requirements at the begging of the design process. In most cases, the top management adopted Voice of the Customer (VOC) and Voice of the Process (VOP) as tools to make appropriate process decision.

Okafor, G., Agbaeze, E., Ekoja, G., \& Obamen, J. (2018). Effect of six sigma on performance of medium scale manufacturing firms in south-eastern Nigeria. International Research Journal of Management,

IT and Social Sciences, 5(4), 26-45. https://doi.org/10.21744/irjmis.v5n4.253 


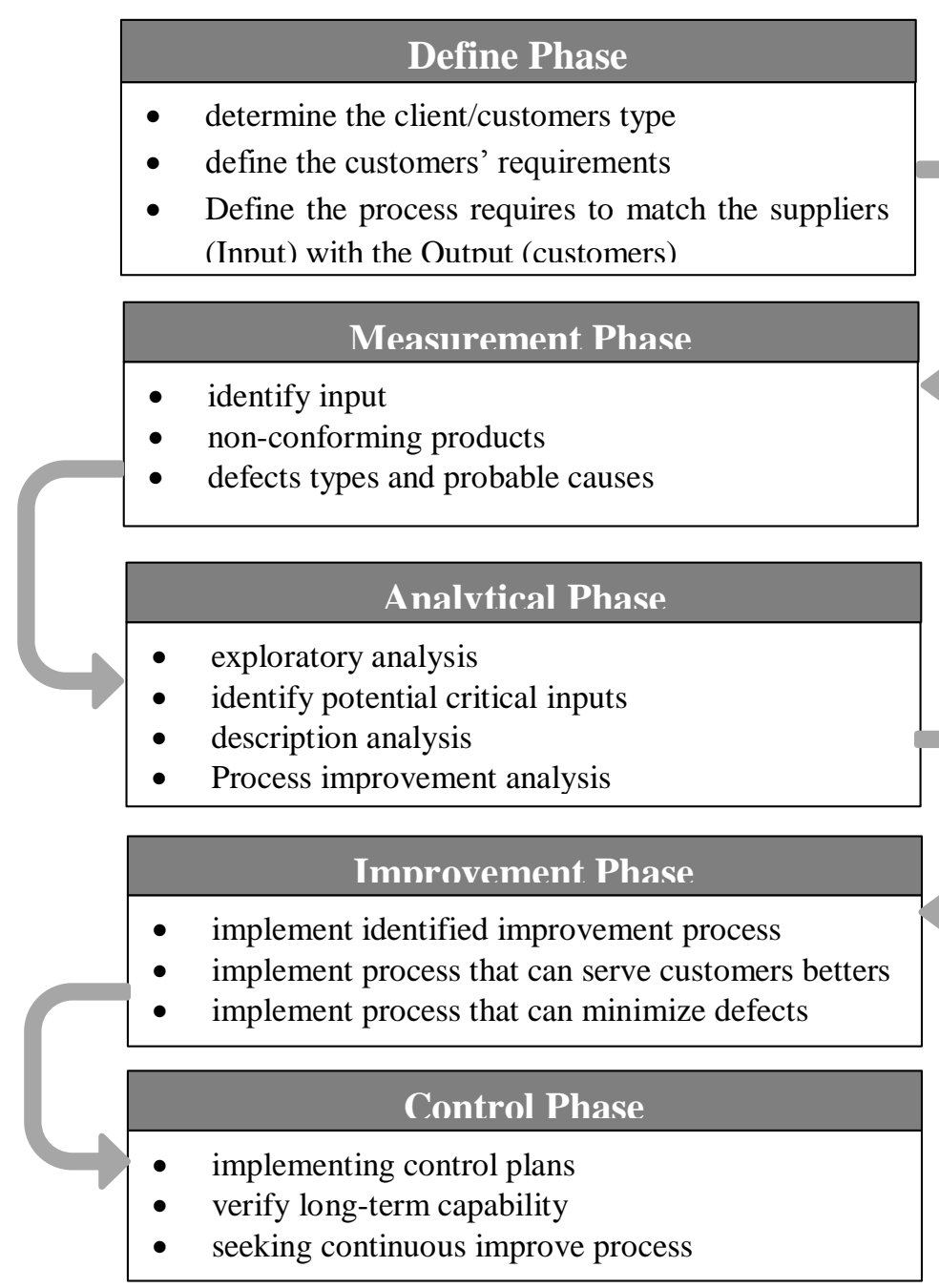

Figure 1: Phases of Six Sigma Method

Source: Adapted from Dileep and Rau (2010). Patient Satisfaction as an Indicator of Quality Care.-A Study With Reference To Six Sigma Implementation in Medium Scale Hospitals

b) Measurement Phase

The purpose of this step is to establish current baselines as the basis for improvement objectively. This is a data collection step, the purpose of which is to establish process performance baselines. The performance metric baseline(s) from the measured phase is expected to be compared to the performance metric at the conclusion of the project, to determine objectively whether significant improvement has been made. The top management in an organization decides on what should be measured and how to measure it. It is usual for a firm to invest a lot of effort into assessing the suitability of the proposed measurement systems. Good data are at the heart of the DMAIC process and to achieve this, data on inputs to every processing, data on non-conforming products and data on a defect in terms of type and possible causes, have to be obtained.

c) Analyze Phase

The purpose of this step is to identify, validate and select root cause for elimination. A large number of potential root causes (process inputs, $\mathrm{X}$ ) of the project problem are identified via root cause analysis. The top 3-4 potential causes are selected using multi-voting or another consensus tool for further validation. A data collection plan is created, and data are collected to establish the relative contribution of each root causes to the project metric, Y. 
This process is repeated until "valid" root causes can be identified. Within Six Sigma, often complex analysis tools are used. According to REF, it is acceptable to use basic tools to determine the root cause whenever the firm deems these tools are appropriate. However, to validate a particular tool for root causes determination, the following may need to be considered togetherness or individual:

1) Listing and prioritizing the potential causes of the problem

2) Prioritizing the root causes with the aim to pursue an improved step

3) Determining how the process inputs (Xs) affect the process outputs (Ys). Data have to be analyzed to understand the magnitude of the contribution of each root cause, $\mathrm{X}$, to the project metric, $\mathrm{Y}$ some statistical tests using p-values, which might also be accompanied by Histograms, charts, and line plots are required.

4) Also, detailed process maps can be created to help pinpoint where in the process the root causes reside, and what might be contributing to the occurrence.

d) Improve Phase

Enofe (2010) opines that the main purpose of improving step is to identify, test and implement a solution to the problem, either in part or whole, the appropriateness of solution depends on the situation. The improved step requires identification of creative solutions to eliminate the key causes in order to fix and prevent process problems. At this stage, there is need critical brainstorming or techniques like Six Thinking Hats and Random Word. In some organizations, the nature of their projects can require complex analytical tools like DoE (Design of Experiments). Whatsoever, the nature of process may be, it is required of top management, to focus on obvious solutions that are apparent. However, Hussan (2013) expresses that the purpose of this step is to find solutions and to implement them. Thereby, each firm needs to put the following into practices:

1) Create

2) Focus on the simplest and easiest solutions

3) Test solutions using Plan-Do-Check-Act (PDCA) cycle

4) Based on PDCA results, attempt to anticipate any avoidable risks associated with the "improvement" using the Failure mode and effects analysis (FMEA)

5) Create a detailed implementation plan

6) Deploy improvements

e) Control Phase

The next or last stage in Six Sigma deployment (after the implementation of improvement efforts) is the institutionalization of the improvement. This stage aimed at locking in the benefits of the optimization and preventing the system from returning to its former state. Hasan (2012) expresses that at this stage all hands have to be on deck to ensure that gains from improvement are sustained, by ensuring monitoring of the improvements toward sustainable success. In most cases, each firm requires the creation of a control plan, which its record has to be updated on a timely basis. Maleka, Hove, and Karodia (2014) suggest that a control chart can be useful during the control stage to assess the stability of the improvements over time by serving as a guide to continue monitoring the process and to provide a response plan for each of the measures being monitored in case the process becomes unstable. All the phases in the six sigma process are to ensure a business development approach that eliminates waste, increase profitability, to reduce costs linked with humble quality, and to improve the efficiency and effectiveness of operations (Weinstein, 2010:572).

\section{Perceived Drawbacks to the Adoption of Six Sigma Practices}

Research has alleged some criticisms of Six Sigma practices often adopted by organizations to include:

a) Stress: The single biggest criticism of Six Sigma is that the constant focus on improvement and elimination of waste becomes an obsession for the firm and causes stress among the workforce and reduced job motivation as result of burn-out. Evidently, the high-stress levels can have determinable effects on productivity and efficiency.

b) No Margins for Error: Six Sigma allows for no safety stock or margin of error, and vilifies any deviance from the codified optimal process. While striving for such perfection leads to better performance, attaining such precision standards may not always be possible, and most at times, unrealistic owing to vagaries of the external environment and human natures. For instance, traffic jams can delay the arrival of an inventory and thereby, hold up production. Similarly, excellent employees might have certain off days where they do not work at their productive best. Attempt

Okafor, G., Agbaeze, E., Ekoja, G., \& Obamen, J. (2018). Effect of six sigma on performance of medium scale manufacturing firms in south-eastern Nigeria. International Research Journal of Management, IT and Social Sciences, 5(4), 26-45. https://doi.org/10.21744/irjmis.v5n4.253 
to keep to the operational standard at all time may make the plants and other production equipment to have unavoidable faults, which might result in total failure (Okonkwo and Mbachu. 2015).

c) Over-Focus on Waste: The critics of Six Sigma pointed at its over-focus on the elimination of waste, which tends to override other concerns. The Six Sigma strives to ensure productivity and efficiency primarily through cutting flab, but in the process, ignores other crucial parameters such as employee wellness, and corporate social responsibility. A company, for instance, might recruit additional workers than necessary as part of its Corporate social responsibility necessary to establish good relationships with local communities. However, efforts to get rid of waste in the production may affect the idea of engaging more staff among the member of communities. Similarly, top management might need to spend an extensible amount of time to lobby and socialize with external agencies to secure orders and negotiate extensively. The Six Sigma does not cater to such unconventional requirements.

d) Over-Focus on Present; the critics of Six Sigma argued that the process only focus to eliminate waste constantly and to ensure optimal output, which results in places all energy on the present. They argued further that Six Sigma does not allow reflection or experimentation for the sake of development in the future. The rule remains do not go below yesterday. Therefore, efforts to beyond are not so important. Such a focus on only the present may lead to missing out on the bigger picture, failing to comprehend the relevance of the task in the first place, or taking time to anticipate future challenges and make necessary changes to respond to such challenges. Lean also stifles creativity, innovation, or experimentation, which not only hampers the organization from responding to changes better but also makes it difficult to realize sudden opportunities that have become the norm in a fast-changing external environment.

However, Umude-Igbruand Brian, 2015 \& Onwughalu, Okeke, and Henry-Chibor (2017) argues that the review of the criticisms levied against Six Sigma suggests that much of the drawbacks stem from the method of implementation rather than any inherent flaw in the practice. They suggested that proper planning, good implementation by incorporating effective change management practices and leadership, stress management interventions, and effecting a change of culture so that each member of the workforce inculcates the philosophy of Sig Sigma, help resolve much of the limitations of using Six Sigma and overcoming the criticism of Lean manufacturing.

\section{The Concept of Small and Medium Scale Industry}

In Nigeria, the Small and medium industries, Equity Investment Scheme (SMIEIS), define small and medium scale industries as enterprises with a total capital not less than N1.5 million and not exceeding N200 million, including working capital, but excluding cost of land and/or with a staff strength of not less than 10 and not more than 300 . Industry or business in Nigeria has been classified as small, medium and large. There is yet to be an accepted definition of a small business because the classification of businesses into large-scale or small-scale is a subjective and qualitative judgment and varies across nations and difference economy environments. The likes of USA, Britain, Canada and other advanced nations defined the small and medium scale business based on their annual turnover and the number of paid employees (Pasanen, 2010). In Britain, small and medium scale business set to be an industry with an annual turnover of not less than 2 million pounds with fewer than 200 paid employees. In Japan, small and medium scale industry is defined according to the type of industry, paid-up capital and number of paid employees. In short, Japan defined its small and medium-scale enterprises as those in manufacturing with 100 million yen paid-up capital and 300 employees. Likewise, those in a wholesale trade with 30 million yen paid-up capital and 100 employees, and those in the retail and service trades with 10 million yen paid-up capital and 50 employees (Eze, 2012).

In an attempt to make a clear definition of small and medium scale industry, Baloyi (2010) argues that it is likely for a firm within the same sector, to be 'small' by capitalization and be large by virtue of numbers of people employed. In short, there were no distinctions between micro, small and medium scale enterprises. The only distinction was drawn between small and large enterprises. In the recent time, the Central Bank of Nigeria (CBN) puts the employment level of the small-scale businesses at less than 50 and medium scale businesses as less than 100. In terms of asset-based, small-scale has less than N1 million while medium-scale has less than N150 million (Fatoki and Garwe, 2010). Whichever, approach takes to define small scale or medium scale it becomes obvious that no clear, distinct definition will be succeeded in creating a clear-cut margin between small scale and medium scale enterprises. 
The Concept of Organisation Performance

Eliot (2007) looks at business performance as "a set of management and critical procedures that allows the management of an organization's performance to accomplish one or more pre-selected goals." There are many indicators that measure it as Darabi (2007) defines a number of business performance objectives and subjective measures such as financial or market-based measures like capacity utilization, market share, profitability, service quality, customer satisfaction, retention and employees' satisfaction. At the organizational level, the financial performance (profits), capital market or shareholder return and product market performance (sales) make up corporate financial performance measures (De Cieri et al., 2010). However, Daniel (2009) argues that "it is worth noting that perceptual measurement scales offer a broader scope to the definition of performance than the objective measurement scales." Thus, the perceptual measures offer the inclusion of non-financial performance segments which are characterized by customers' satisfaction, customers' retention and quality service (Gavrea and Stegerean, 2011). De Cieri (2010) express that organizations do put in place various measures to determine their performance at the individual and organizational level. A focus on a broader conceptualization of performance enables performance to be viewed from diverse perspectives. Okoro and Washington (2012) agree with the perceptual measures, which provide opportunities for industries to make comparisons easily than financial indicators would. Not only that, the financial performance measures are characterized by difficulty in acquiring objective data because organizations (mostly private companies) are normally unwilling to provide its correct data to the public. Financial measures face the challenge of overcoming the criticism that it is one-dimensional and thus, it offers limited services (Hussain, Gunasekaran, and Islam 2002).

Another approach to the evaluation of organization performance is known as non-financial performance measures; this is the measurement of the organization's output and productivity devoid of monetary units (Malgharni Wan-yusoff, and Arumugam, 2011). Many organizations focus on controlling and measuring their productivity in monetary terms (sales, revenue, and profit). However, managers admit the intangible aspect of productivity (exemplified by nonfinancial performance measures) is where contemporary organizations compete. In some instances, some organizations are gauging themselves in regard performance in the aspect of customer service with the conviction that rendering quality service will translate into high customer retention as well as increased profits (Durga-Prasad, 2017). The usefulness of non-financial performance has grown so much that some reviews make the use of non-financial performance appear flawless. Some analysts have argued that non-financial performance is consistent in measuring the status of organization than using financial performance. In one of earlier studies by Jonathan, Moorthy, Annie, Choo, Chang, and Tan-Kah. (2012), it was retorted that shortcomings of nonfinancial performance could only be attributed to wrongful implementation and usage. The rise of competitive situations such as providing solutions to customer expectations, customization of services, business-community interaction, employee-firm interaction, employees manageability, the corporate sustainability and adoption of other current practices have taken center stage of measures organization performance. The appropriateness of in terms of timeliness, total quality measurement, and management effectiveness have to render accounting-based systems for measuring performance as inadequate (Jonathan et al., 2012). On the other hand, non-financial performance faces the critique of being subjected to time. The differences are narrowed to the view that financial indicators that measure performance focus on profitability (example, return on investment) and limits performance to short term. In contrast, the fact remains that long-term profitability for organizations is characterized by non-financial elements such as quality, employee and customer relations (Hussain et al., 2002). The idea of quality service, corporate image, customers' loyalty and quality product is not quantifiable and thus much preferable to non-financial measurements than the financial. The non-financial measures are flexible enough to capture the quality dimensions and importance of quality to output (Jonathan et al., 2012).

\section{Theoretical Framework}

This study is anchored on knowledge-based theory propounded by Robert Morris Grant in 1996.

\section{Knowledge-Based Theory}

The knowledge-based theory of the firm focuses on intangible resources, rather than on physical assets. The knowledge-based theory of the firm recognizes knowledge as a key resource of the firm and a source of competitive advantage that improves firm performance (Davenport and Prusak, 1998). According to knowledge-based theorists, such as Kogut and Zander (1996); and Davenport and Prusak (1998), firms were conceptualized as distributing the

Okafor, G., Agbaeze, E., Ekoja, G., \& Obamen, J. (2018). Effect of six sigma on performance of medium scale manufacturing firms in south-eastern Nigeria. International Research Journal of Management, IT and Social Sciences, 5(4), 26-45. https://doi.org/10.21744/irjmis.v5n4.253 
repositories of tacit and explicit knowledge, whose heterogeneous knowledge-bases are the key determinants of sustained competitive advantage? Thus, capabilities to manage and create knowledge by the top manager can provide a sustainable competitive advantage (Argyris, 1999; Green, 2010). The Six Sigma process aims to feed the firms' management with the needed knowledge about their organization that can contribute to competitive advantage by institutionalizing continuous improvement of business processes (De Mast, 2009).

\section{The implication of the knowledge-based theory}

A knowledge-based theory of the firm can help to understand how the knowledge creation in Six Sigma can have substantial effects on the organization performance (Davenport and Prusak, 1998; Grant, 1996; Kogut and Zander, 1996). The theory assumes that Six Sigma affect organizational performance through knowledge processes. Because many factors influence the determination of organizational performance, whereas, only Six Sigma explore or investigate every stage of manufacturing process, which give no room for the over sighted situation.

\section{Empirical Studies}

Numerous empirical studies have examined the relationship between Six Sigma and their effects on organizational performance. A study by Agina-Obu (2015) investigated the rate of applicability of Six Sigma in Nigerian fabrication companies using Aveon Offshore in Port Harcourt as a study case. The study used a semi-structured set of questions were drawn for in-depth interviews of twenty participants and data obtained were analyzed using Thematic Network Analysis. The study found that most top managers still preferred ISO 9001 to Six Sigma as results of lack of full understanding of Six Sigma, fear of change of process, cost of retaining staff and modification or acquired of modern production machinery. Abidakun, Leramo, Ohunakin, Babarinde, and Ekundayo-Osunkoya (2014) conducted an empirical study to determine the suitability of Six Sigma technique on Nigerian fabricating industry. The study adapted DMAIC to an aluminum mill to identify sources and causes of waste with the intention of providing veritable solutions. The study found a sigma level of 1.87 in the aluminum milling firm which indicated the existence of opportunities for improvement, to reduce the re-work or defects in this firm $37.05 \%$ of total production, to $4.1 \%$ if Six Sigma technique is applied. The study recommended that the manufacturing firm should switch from various standard production techniques such as ISO 9001 and TQM to Six Sigma if the manufacturing firm in Nigeria wanted a noticeable improvement that can lead to the firm operating with near- perfect processes, with minimal waste and rework. Enoch (2013) carried out empirical study examined the effect of Six Sigma Methodologies on Organizational Profitability among the Manufacturing SMEs in Nigeria. The population of the study contained 450 manufacturing SMEs with 2250 employees. The study made up a sample of 225 MSMEs with total 1026 employees selected randomly. The study used structured questioners to collect data and total 1002 respondents duly filled and returned their questionnaire. The study used product moment correction (PPMC) confirmed the formulated propositions with a negative association between awareness, Six Sigma implementation and achieved critical success factors as well as the profitability level among participating MSMEs. The findings from the study showed that Six Sigma implementation among MSMEs in Nigeria was almost non-existing and had no influence on the profit level. The study recommended that CEOs of MSMEs should start training on Lean Six Sigma to allow them to provide strong leadership. The study by Reddy and Reddy (2010) titled: "Process improvement using Six Sigma - a case study in the small-scale industry." The study was aimed at process improving using Six Sigma at bearing manufacturing facility in Hyderabad. The study applied the Six Sigma project on improving the rejection rate of bearing rings. The study found that as result of adopting Six Sigma process, there was a significant reduction in the product variation as a result of statistical thinking. Likewise, it was established in the study that as results of various statistical tools and techniques used during Six Sigma measure and analysis stages, the rejection rate of bearing rings has been reduced from $2.7 \%$ to $0.65 \%$ as sigma level of process increased from 4.04 to 4.44 . The study recommends that the bearing industry should intensify to fully implement the Six Sigma, to completely get over the variation defect in its productions as well as completely reducing the rejection rate. Moosaa and Sajid (2010), critically analyzed the Six Sigma implementation, to determine the success and failure factors of implementing Six Sigma in organizations. The study was based on case studies, as well as secondary data through available literature. The study found from extensively reviewed literature, and real-life case study investigation of those firms implemented Six Sigma processes that majority of firms adopting Six Sigma recorded more success rate with few instances of failure rate. The study concluded that the CEOs and top managers in the firms should fully implement Six Sigma and train their staff on how to implement Six Sigma effectively. Kateeb (2009) examined the extent of unplanned Six Sigma using in Housing Bank for Trade and Finance in Turkey. The study used a structured 
questionnaire to randomly collect data from 120 employees working in Housing Bank for Trade and Finance and 310 customers. The study established a significant statistical relationship between Six Sigma changes on mistake reduction, the significant statistical relationship between Six Sigma on time circle reduction. The study concluded that if the top management in the Housing Bank for Trade and Finance have a plan to implement the Six Sigma fully, the efficiency of Housing Bank for Trade and Finance will increase and their waste will completely minimize. Also, the study by Desai (2008) has established that Six Sigma practices can improve productivity as well as the profitability of smallscale industries irrespective of their location and market type. $\mathrm{Zu}$ (2005) examined the joint effects of Six Sigma and TQM practices on quality and business performance in organizations. The findings from the study reveal that Six Sigma model positively improved the quality and financial performance of the organization. Also, the adoption of Six Sigma was found effectively supporting traditional quality practices, which well positioned firm's products among local and national markets. Obaidullah (2005) conducted an empirical study to the extent of implementation of Six Sigma in UK organizations. The study found that across both manufacturing and service organizations in the UK, the Six Sigma has been fully applied. Though, the study found that some firms are yet to be at $100 \%$ implementation while some have less than six to nine months to complete Six Sigma project fully. More so, the project found that less than $40 \%$ of employees have been training on six sigma implementation, which makes it difficult for the top management to give descriptive power to the staff. The study recommends for the immediate and adequate training of employees on Six Sigma process that can facilitate the full implementation and desired organizational performance. Likewise, the study by Flora (2003) that examined the contrasting impact between Six Sigma and TQM on financial performance in US companies, the findings from the study indicated that the Six Sigma management philosophy was a more effective agent for financial success in manufacturing firms than the TQM philosophy.

\section{Summary of the Literature}

Among the few types of research on the level of Six Sigma adoption and its effect on Nigerian firm is the study conducted by Agina-Obu (2015) which revealed a low level of application of Six Sigma among Nigerian fabrication companies. Also, the study by Abidakun Leramo, Ohunakin, Babarinde, and Ekundayo-Osunkoya (2014) has proved the suitability of Six Sigma to Nigerian industries in contrast to the thinking of many top managers that, adopting Six Sigma implies total changing of an operational process. Likewise Enoch (2013), which found a low level of adoption and high rate of fault and design waste with unending rework among Nigerian manufacturing firms. more so, a study by Reddy and Reddy (2010) indicated that in spite the fact that the bearing manufacturing company in Hyderabad fully aware of the effectiveness of Six Sigma in attaining operational accuracy, the level of adoption of Six Sigma is below average. However, a study by Obaidullah (2005) indicated that manufacturing firms in the UK are yet to fully adopt Six Sigma after a period of 3 decades of introduction, while only $40 \%$ of the staff have been trained in line with Six Sigma process in the most organization. The findings of effectiveness were reported in the study by $\mathrm{Zu}(2005)$ on the effect of Six Sigma on organizational performance. Likewise, the study by Flora (2003) reaffirmed the effectiveness of Six Sigma in terms of organization performance over TQM. More so, the study by Lee (2002) indicates that Six Sigma had positive effects on operational performance and customer satisfaction. In overall, it has evidence from the reviewed study that most research studies on application and effectiveness of Six Sigma technique were conducted outside Nigeria, while the few conducted in Nigeria are yet to pinpoint whether there is any contribution of Six Sigma on organization performance or not. This study, therefore, chooses to investigate the effectiveness of Six Sigma technique on medium scale manufacturing firms using South-Eastern part of Nigeria, where hosts of manufacturing firms are located.

Okafor, G., Agbaeze, E., Ekoja, G., \& Obamen, J. (2018). Effect of six sigma on performance of medium scale manufacturing firms in south-eastern Nigeria. International Research Journal of Management, IT and Social Sciences, 5(4), 26-45. https://doi.org/10.21744/irjmis.v5n4.253 


\section{Results and Analysis}

\subsection{Result and Analysis of the Research Questions}

Table 1

Influence of Process Definition on Customers Patronage of the Product of the Medium Scale Manufacturing Firms in South-Eastern Nigeria

\begin{tabular}{|c|c|c|c|c|c|c|c|c|}
\hline$S / n$ & Items & $\begin{array}{c}\text { SA } \\
\text { Fx }(\%)\end{array}$ & $\begin{array}{c}\mathrm{A} \\
\text { Fx }(\%)\end{array}$ & $\begin{array}{c}\mathrm{U} \\
\text { Fx }(\%)\end{array}$ & $\begin{array}{c}\mathrm{D} \\
\text { Fx }(\%)\end{array}$ & $\begin{array}{c}\text { SD } \\
\text { Fx }(\%)\end{array}$ & Avg & Rmk \\
\hline 1 & $\begin{array}{l}\text { Your firms efforts to } \\
\text { determine the type of } \\
\text { customers before } \\
\text { embarking on production is } \\
\text { highly effective }\end{array}$ & $121(65 \%)$ & $32(17 \%)$ & $12(6 \%)$ & $7(4 \%)$ & $15(8 \%)$ & 4.27 & A \\
\hline 2 & $\begin{array}{l}\text { Listening to voices from } \\
\text { customers before } \\
\text { production is enhancing } \\
\text { patronages of your firm } \\
\text { product }\end{array}$ & $38(20 \%)$ & $98(52 \%)$ & $3(2 \%)$ & $32(17 \%)$ & $16(9 \%)$ & 3.59 & A \\
\hline 3 & $\begin{array}{l}\text { Predetermine every } \\
\text { activities before } \\
\text { commencement of } \\
\text { production is aiding your } \\
\text { firm to meet customers' } \\
\text { demand }\end{array}$ & $7(4 \%)$ & $23(12 \%)$ & $34(18 \%)$ & $76(41 \%)$ & $47(25 \%)$ & 2.29 & D \\
\hline 4 & $\begin{array}{l}\text { The efforts by planning unit } \\
\text { of your firm that ensures } \\
\text { channeling of product to the } \\
\text { final consumers are } \\
\text { yielding more patronage }\end{array}$ & $34(18 \%)$ & $94(50 \%)$ & $3(2 \%)$ & $21(11 \%)$ & $35(19 \%)$ & 3.38 & A \\
\hline 5 & $\begin{array}{l}\text { The list of activities used } \\
\text { by planning unit in your } \\
\text { firm before embarking on } \\
\text { production is helping the } \\
\text { firm to address the } \\
\text { consumers' demand rightly }\end{array}$ & $101(54 \%)$ & $67(36 \%)$ & $2(1 \%)$ & $16(9 \%)$ & $1(1 \%)$ & 4.34 & A \\
\hline
\end{tabular}

SA: strongly agree, A: Agreed, U: undecided, D: Disagreed, SD: Strongly Disagreed, Avg: Average, Rmk: Remarks

The results in Table 1 shows that the perspectives of employees from medium scale manufacturing firms from SouthEastern Nigeria on the influence of process definition on their respective firm's products. Thus, the results across the table showed that determine or define the type of customers before production enhancing patronage, this fact was strongly agreed to by $65 \%$ of respondents (average $=4.27$ ). Also, $52 \%$ of respondents agreed that listening to voices or comments from customers before production is enhancing patronage of their product (average $=3.59$ ). However, the predetermination of every activity before production is yet to be yielding expected results among the manufacturing firms. This fact was confirmed by $41 \%$ and $25 \%$ of the respondents that disagreed and strongly disagreed with the assertion that predetermination of the process is aiding the firm in meeting customers demand (average $=2.29$ ). The channeling effort from planning unit in the selected manufacturing firms is promoting patronage. This fact was reaffirmed by $50 \%$ respondents (average $=3.38$ ). More so, 54 of respondents unanimously agreed that listing activities before embarking on production were aiding the firm to address the consumer needs (average $=4.34$ ) rightly. In short, 
the results on Table 1 reaffirmed that define production process, which was one of the six sigma phased is keen to the customers' patronage of the product of medium scale manufacturing firm in South-Eastern Nigeria.

Table 2

Influence of Process Measure on Positioning the Products of Medium Scale Manufacturing Firms in South-Eastern Nigeria

\begin{tabular}{|c|c|c|c|c|c|c|c|c|}
\hline $\mathrm{S} / \mathrm{n}$ & Items & $\begin{array}{c}\text { SA } \\
\mathrm{Fx}(\%)\end{array}$ & $\begin{array}{c}\mathrm{A} \\
\mathrm{Fx}(\%)\end{array}$ & $\begin{array}{c}\mathrm{U} \\
\mathrm{Fx}(\%)\end{array}$ & $\begin{array}{c}\mathrm{D} \\
\mathrm{Fx}(\%)\end{array}$ & $\begin{array}{c}\text { SD } \\
\mathrm{Fx}(\%)\end{array}$ & Avg & Rmk \\
\hline 1 & $\begin{array}{l}\text { The understanding of } \\
\text { external and intervening } \\
\text { inputs to the production } \\
\text { process in your firm is } \\
\text { giving your product } \\
\text { recognition }\end{array}$ & $5(3 \%)$ & $12(6 \%)$ & $45(24 \%)$ & $35(19 \%)$ & $90(48 \%)$ & 1.97 & $\mathrm{D}$ \\
\hline 2 & $\begin{array}{l}\text { The constant awareness } \\
\text { about the possibility of } \\
\text { the non-conforming } \\
\text { product before or during } \\
\text { the production process by } \\
\text { your firm is giving your } \\
\text { product good attribute }\end{array}$ & $31(17 \%)$ & $79(42 \%)$ & $31(17 \%)$ & $23(12 \%)$ & $23(12 \%)$ & 3.39 & A \\
\hline 3 & $\begin{array}{l}\text { The automatic collection } \\
\text { of data on various } \\
\text { production defects in your } \\
\text { firm is influenced } \\
\text { customers satisfaction }\end{array}$ & $21(11 \%)$ & $34(18 \%)$ & $3(2 \%)$ & $12(6 \%)$ & $117(63 \%)$ & 2.09 & $\mathrm{D}$ \\
\hline 4 & $\begin{array}{l}\text { The automatic collection } \\
\text { of data on possible causes } \\
\text { of product defects in your } \\
\text { firm is ensuring brand } \\
\text { image in the markets }\end{array}$ & $56(30 \%)$ & $87(47 \%)$ & $23(12 \%)$ & $13(7 \%)$ & $8(4 \%)$ & 3.91 & A \\
\hline 5 & $\begin{array}{l}\text { Determination of the } \\
\text { precise costs of } \\
\text { production before } \\
\text { embarking on production } \\
\text { process is enhancing the } \\
\text { suitability of your firm } \\
\text { product to the customers } \\
\text { taste }\end{array}$ & $32(17 \%)$ & $92(49 \%)$ & $14(7 \%)$ & $23(12 \%)$ & $26(14 \%)$ & 3.43 & A \\
\hline
\end{tabular}

SA: Strongly Agree, A: Agreed, U: Undecided, D: Disagreed, SD: Strongly Disagreed, Avg: Average, Rmk: Remarks

The results in Table 2 reveal the perspectives of sampled employees from medium scale manufacturing firms in SouthEastern Nigeria. The results showed that $48 \%$ of respondents unanimously disagreed with the assertion that their firms understand the external and intervening inputs to the production process that can yield product recognition (average $=$ 1.97). More so, $42 \%$ of respondents agreed to the assertion that constant awareness about the possibility of the nonconforming product before or during the production process by their firms was yielding good product attribute (average=3.39). Most sampled employees (63\%) from manufacturing firms in south-eastern Nigeria unanimously disagreed to the assertion that their firms had a mechanism to automatically collect data on various production defects to influence customers satisfaction (average $=2.09$ ). However, $47 \%$ of respondents expressed that their firms put in

Okafor, G., Agbaeze, E., Ekoja, G., \& Obamen, J. (2018). Effect of six sigma on performance of medium scale manufacturing firms in south-eastern Nigeria. International Research Journal of Management,

IT and Social Sciences, 5(4), 26-45. https://doi.org/10.21744/irjmis.v5n4.253 
place mechanism that can provide automatic collect data on possible causes of product defects in an attempt to ensure brand image (average=3.91). Most employees $(50 \%)$ from selected manufacturing firms in south-eastern Nigeria, expressed that, their firms are to determine the precise cost of production before the commencement of production in the bids to enhance the suitability of their products to the customers' taste (average $=3.43$ ).

Table 3

Influence of Process Improvement on Customers' Retention among Medium Scale Manufacturing Firms in South-Eastern Nigeria

\begin{tabular}{|c|c|c|c|c|c|c|c|c|}
\hline $\mathrm{S} / \mathrm{n}$ & Items & $\begin{array}{c}\mathrm{SA} \\
\mathrm{Fx}(\%)\end{array}$ & $\begin{array}{c}\mathrm{A} \\
\mathrm{Fx}(\%)\end{array}$ & $\begin{array}{c}\mathrm{U} \\
\mathrm{Fx}(\%)\end{array}$ & $\begin{array}{c}\mathrm{D} \\
\mathrm{Fx}(\%)\end{array}$ & $\begin{array}{c}\text { SD } \\
\mathrm{Fx}(\%)\end{array}$ & Avg & Rmk \\
\hline 1 & $\begin{array}{l}\text { Prompt response in } \\
\text { applying necessary solution } \\
\text { for fixing defect in } \\
\text { production is promoting } \\
\text { customer trust }\end{array}$ & $89(48 \%)$ & $45(24 \%)$ & $2(1 \%)$ & $12(6 \%)$ & $39(21 \%)$ & 3.71 & A \\
\hline 2 & $\begin{array}{l}\text { The immediate responses to } \\
\text { the needs of consumers by } \\
\text { the top management are } \\
\text { promoting service or } \\
\text { product customization to } \\
\text { suit customers' needs }\end{array}$ & $97(52 \%)$ & $31(17 \%)$ & $6(3 \%)$ & $34(18 \%)$ & $19(10 \%)$ & 3.82 & A \\
\hline 3 & $\begin{array}{l}\text { Meeting financial } \\
\text { obligation for the } \\
\text { maintenance of equipment } \\
\text { and production plants in } \\
\text { your firm is promoting } \\
\text { customers' loyalty }\end{array}$ & $67(36 \%)$ & $92(49 \%)$ & $5(3 \%)$ & $13(7 \%)$ & $10(5 \%)$ & 4.03 & A \\
\hline 4 & $\begin{array}{l}\text { Bringing an expert on board } \\
\text { to determine the problem in } \\
\text { the production by your firm } \\
\text { is enhancing the suitability } \\
\text { of the product to customers } \\
\text { taste }\end{array}$ & $45(24 \%)$ & $78(42 \%)$ & $4(2 \%)$ & $21(11 \%)$ & $39(21 \%)$ & 3.37 & A \\
\hline 5 & $\begin{array}{l}\text { The prompt implementation } \\
\text { of the suggested solution is } \\
\text { perfecting the products and } \\
\text { enhancing competitive } \\
\text { advantages in the markets }\end{array}$ & $99(53 \%)$ & $43(23 \%)$ & $12(6 \%)$ & $21(11 \%)$ & $12(6 \%)$ & 4.05 & A \\
\hline
\end{tabular}

The results in Table 3 revealed the influence of process improvement on customers' retention among medium scale manufacturing firms in south-eastern Nigeria. The results showed that $48 \%$ of respondents unanimously agreed that prompt response in applying necessary solution for fixing a defect in production is promoting trust among customers (average $=3.71$ ). Also, $52 \%$ of respondents expressed that the immediate responses to the needs of consumers by the top management are promoting service or product customization (average $=3.82$ ). Likewise, $49 \%$ of respondents expressed that the ability of the top management to meet the financial obligation for the maintenance of equipment and production plants is ensuring prompt production that influences customers' loyalty (average $=4.03$ ). More so, $42 \%$ of respondents unanimously agreed that bringing an expert on board when solving the problem in the production is enhancing the suitability of their firms' products to customers taste (average $=3.37$ ). Also, 53\% of respondents 
expressed that the prompt implementation of a solution to the production problem is perfecting the products and enhancing competitive advantages in the markets (average=4.05).

\subsection{Test of Hypotheses}

$\mathrm{H}_{\mathrm{O} 1}$ : There is a significant relationship between the level of process definition and customers' patronage of the products of medium scale manufacturing firms in south-eastern Nigeria.

Table 4

Results of Pearson Product Moment Correlation on the relationship between the level of process definition and customer's patronage of the products of medium scale manufacturing firms in South-Eastern Nigeria

\begin{tabular}{lccc}
\hline Stat & Value & Asymp. Std. Error ${ }^{\mathrm{a}}$ & Sig. \\
\hline Pearson's R & .722 & .059 & .001 \\
N of Valid Cases & 187 & & \\
\hline
\end{tabular}

The result in Table 4 showed a strong correlation value 0.72 which is significant at $\mathrm{p}<0.05$. This result showed that there is a strong positive relationship between the level of process definition and customers patronage, thereby, the null hypothesis is stated that there is no significant relationship between the level of process definition and customers' patronage of the products of medium scale manufacturing firms in south-eastern Nigeria, is rejected.

$\mathrm{H}_{\mathrm{O} 2}$ : There is a significant relationship between the level of process measure and positioning of products of medium scale manufacturing firms in South-eastern Nigeria.

Table 5

Results of Pearson Product Moment Correlation on the relationship between the level of process measurement and product positioning among the medium scale manufacturing firms in South-Eastern Nigeria

\begin{tabular}{lccc}
\hline Stat & Value & Asymp. Std. Error $^{\mathrm{a}}$ & Sig. \\
\hline Pearson's R & .801 & .071 & .000 \\
N of Valid Cases & 187 & & \\
\hline
\end{tabular}

The result in Table 5 revealed a positive correlation value 0.801 , significant at $\mathrm{p}<0.05$. This result established a strong positive relationship between the level of process measurement and products positioning for the manufacturing firm in south-eastern Nigeria. Therefore, the null hypothesis that expressed the possibility of an insignificant relationship between the level of process measure and positioning of products of medium scale manufacturing firms in Southeastern Nigeria is rejected.

Ho3: There is no significant relationship between the level of productivity improvement strategy and level of customers' retention among the medium scale manufacturing firms in south-eastern Nigeria.

Table 6

Results of Pearson Product Moment Correlation on the relationship between the level of productivity improvement strategy and level of customers' retention among the medium scale manufacturing firms in South-Eastern Nigeria

\begin{tabular}{lccc}
\hline Stat & Value & Asymp. Std. Error & Sig. \\
\hline Pearson's R & .556 & .073 & .011 \\
N of Valid Cases & 187 & & \\
\hline
\end{tabular}

The result in Table 6 revealed a correlation value 0.556, which is significant at $\mathrm{p}<0.05$. This result established a positive relationship between the level of productivity improvement strategy and level of customers' retention. Thereby, the null hypothesis stated that there is no significant relationship between the level of productivity improvement strategy and level of customers' retention among the medium scale manufacturing firms in south-eastern Nigeria is rejected.

\section{Okafor, G., Agbaeze, E., Ekoja, G., \& Obamen, J. (2018). Effect of six sigma on performance of medium scale manufacturing firms in south-eastern Nigeria. International Research Journal of Management, IT and Social Sciences, 5(4), 26-45. https://doi.org/10.21744/irjmis.v5n4.253}




\subsection{Discussion}

a) The findings from this study showed that process definition is influencing customers' patronage among medium scale manufacturing firm in south-eastern Nigeria. Likewise, the result from Pearson product moment correlation (PPMC) revealed the highly significant relationship between the level of process definition and customer patronage. This result reaffirmed the significance of definition in the Six Sigma technique in any organization. Defining or determine the type customers, customers' needs as well as identifying resources to achieve the production will ensure consistent patronage from consumers. This finding agreed with the earlier findings made from study conducted by Suleiman (2014), Abidakun et al. (2014) and Oko and Parminder (2015), that defining stage is not only the starting phase of Six Sigma technique but also a determination of the overall effective adaptation of Six Sigma in organizational processes. Likewise, the finding of this study concurs with the finding made by William (2015) that determines the type of customers and customers' needs significantly influence product patronage as well as promoting competitive advantage.

b) The findings from this study also established a process measurement influence of products positioning among the medium scale manufacturing firm in South-Eastern Nigeria. The study finding indicated that taking measure to determine defect and non-conforming production process is minimizing product defects and promoting a close-toperfect product which enhances good product attribute and repositions product brand in the market. Likewise, the finding from secondary research hypothesis established a significant relationship between the level of process measurement and product positioning among medium scale manufacturing in the South-Eastern state of Nigeria. This finding is in accordance with the finding made by Ika (2012), Ibeawuchi and Okwara (2016)and Alexander et al. (2015) that measurement stage of Six Sigma which entails collation necessary data for evaluation is aiding the smooth production as well as ensuring the close-to-perfection product which enhances brand recognition, business image as well as brand or product positioning in the market. In short, taking collating necessary data on type and causes of product defects enhances production effectiveness and can well position the product even in any tighten economic space.

c) The findings of this study also revealed that the improvement of the production process is influencing the customers' retention. This may not be unconnected with the fact that customers that notice continues improvement in the product will like to repeat the purchases as much as they can afford. Also, the findings from third hypotheses established a significant relationship between improvement in product and customer retention. This finding agreed with the finding made by Okpala (2012) and Onwughalu et al. (2017) that adoption of six sigma technique significantly influenced repeat purchases, customer loyalty, and steady market growth. This may not be unconnected with the fact that consistent improvement on the previous product, through equipment maintenance, process upgrading and implementation of corrective measures were keen to bring out the best product that all customers would like to have. Thus, it is evident that improvement in production process promoted the close-toperfect product and simulated brand image, given a competitive advantage and promotes customer loyalty.

\section{Conclusion}

This study has evidence that the adoption of Six Sigma creates a way forward for the manufacturing firms in Nigeria, especially the medium scale manufacturing firms in south-eastern. This study has demonstrated through its findings that the adoption of Six Sigma will facilitate the efficient business-to-customer relationship, position products, improve brand image, aid competition as well as create customer loyalty. The ability of Six Sigma to ensure intimation among the top management, employees, consumers, and people in the host community has been demonstrated in this study, through process definition, customers' identification, listening to the voice of consumer as well as the voice of process.

\section{Recommendations}

Based on the findings and conclusion from this study, the following are the recommendations:

a) The manufacturing firms in South-Eastern Nigeria should fully implement the six sigma technique to promote their productions standard and facilitate their product marketing 
b) The top management in the manufacturing firm in the south-eastern part of Nigeria should include special training on how to implement Six Sigma for the managers and employees

c) The current study recommends that the manufacturing firms in South-Eastern Nigeria should put in place some mechanisms that can capture data on a defect in the production, including type, source and period to enable effective measure and analysis.

Conflict of interest statement and funding sources

The authors declared that they have no competing interest. The study was financed by the authors themselves.

Statement of authorship

The authors have a responsibility for the conception and design of the study. The authors have approved the final article.

\section{Acknowledgments}

Our deep appreciation goes to the Head, Dr. E.K Agbaeze, Department of Management, University of Nigeria, Enugu campus and to Prof Ewurum, J. U, for their guidance and constructive criticism which has culminated in the successful completion of this study, we say thank you.

Okafor, G., Agbaeze, E., Ekoja, G., \& Obamen, J. (2018). Effect of six sigma on performance of medium scale manufacturing firms in south-eastern Nigeria. International Research Journal of Management,

IT and Social Sciences, 5(4), 26-45. https://doi.org/10.21744/irjmis.v5n4.253 


\section{References}

Abdullah, M. N., \& ASMONI, M. (2012). A Structured Critical Success Factors Model for Implementing Project Quality Management System in Construction. Doctor of Philosophy. Universiti Teknologi Malaysia.

Abidakun, O. A., Leramo, R. O., Ohunakin, O. S., Babarinde, T. O., \& Ekundayo-Osunkoya, A. O. (2014). Quality improvement of foundry operation in NIGERIA using six sigma technique. Canadian Journal of Pure and Applied Sciences, 8(1), 2751-2760.

Aghara, V. N., Nwaizugbo, I. C., Oparah, P. C., \& Ifeanyichukwu, C. D. (2018). Sales promotion as a leverage strategy for improving sales and profitability in alcohol beverage industry. International Research Journal of Management, IT and Social Sciences (IRJMIS), 5(4), 18-25.

Al Kunsol, W. H. (2015). The Effect of Lean Six Sigma on the Jordanian Pharmaceutical Manufacturing Organizations' Business Performance (Doctoral dissertation, Middle East University).

Al Kunsol, W. H. (2015). The Effect of Lean Six Sigma on the Jordanian Pharmaceutical Manufacturing Organizations' Business Performance (Doctoral dissertation, Middle East University).

Argyris, C. (1999). On organizational learning. Malden. MA: Blackwell.

Ataollah, M., Wan, F., \& Veeri, C. (2011). The method for measuring and disclosure of non-financial performance. Australian Journal of Basic and Applied Sciences, 5(12), 1133-1145.

Ayeni, F. O. (2003). An empirical study of the impact of Six Sigma methodology on organization financial performance in the United States.

Baloyi, J. K. (2010). An analysis of constraints facing smallholder farmers in the Agribusiness value chain: A case study of farmers in the Limpopo Province (Doctoral dissertation, University of Pretoria).

Blitz, N. M., \& Eliot, D. J. (2007). Anatomical aspects of the gastrocnemius aponeurosis and its insertion: a cadaveric study. The Journal of foot and ankle surgery, 46(2), 101-108.

Dahlgaard, J. J., \& Mi Dahlgaard-Park, S. (2006). Lean production, six sigma quality, TQM and company culture. The TQM magazine, 18(3), 263-281.

Darabi, Y. (2007). The impact of market orientation on business performance and website adoption: a study among Iranian SMEs.

Davenport, T. H., \& Prusak, L. (1998). Working knowledge: How organizations manage what they know. Harvard Business Press.

De Cieri, H., Shea, T., \& Sheehan, C. (2010). Beyond profit: Incorporating societal value into the measurement of organisational performance: A report to participating organisations. Department of Management, Faculty of Business and Economics, Monash University.

De Mast, J. (2006). Six Sigma and competitive advantage. Total Quality Management and Business Excellence, 17(04), 455-464.

Dileep, G., \& Rau, S. (2010). Patient satisfaction as an indicator of quality care.-a study with reference to six sigma implementation in medium scale hospitals. National Journal on Advances in Computing and Management, 1(2).

Douglas, A., Douglas, J., \& Ochieng, J. (2015). Lean Six Sigma implementation in East Africa: findings from a pilot study. The TQM Journal, 27(6), 772-780.

Durga-Prasad, R. (2017). The impact of workforce diversity on organizational effectiveness: (A study of selected banks in Tigray Region of Ethiopia). International Journal of Science and Research (IJSR), 6(1), 63 - 91.

Enoch, O. K. (2013). Lean six sigma methodologies and organizational profitability: A review of manufacturing SMEs in Nigeria. American Journal of Industrial and Business Management, 3(6), 573.

Enofe, O. M., \& Aimienrovbiye, G. (2010). Maintenance impact on Production Profitability-A Case Study.

Gavrea, C., Ilies, L., \& Stegerean, R. (2011). Determinants of organizational performance: The case of Romania. Management \& Marketing, 6(2).

Grant, R. M. (1996). Toward a knowledge-based theory of the firm. Strategic management journal, $17(\mathrm{~S} 2), 109-122$.

Green, F.B. (2010) 'Six Sigma and revival of TQM', Total Quality Management, Vol. 17, No. 10, pp.1281-1286.

Hasan, R. (2002). The impact of imported and domestic technologies on the productivity of firms: panel data evidence from Indian manufacturing firms. Journal of Development Economics, 69(1), 23-49.

Hassan, M. K. (2013). Applying lean six sigma for waste reduction in a manufacturing environment. American Journal of Industrial Engineering, 1(2), 28-35.

Hickman, D. C. (2009). The effects of higher education policy on the location decision of individuals: Evidence from Florida's Bright Futures Scholarship Program. Regional science and urban Economics, 39(5), 553-562.

Hussain, M., Gunasekaran, A., \& Islam, M. M. (2002). Implications of non-financial performance measures in Finnish banks. Managerial Auditing Journal, 17(8), 452-463. 
Ibeawuchi, I. E. andOkwara, I (2016).Technological factors for improved productivity of manufacturing projects in the South-East Geopolitical Zone of Nigeria Technological Factors for Improved Productivity of Vol. V, Issue XII $1-19$

Ifeanyichukwu, C. D., \& Peter, A. (2018). The Role of Sensory Marketing in Achieving Customer Patronage in Fast Food Restaurants in Awka. International Research Journal of Management, IT and Social Sciences (IRJMIS), 5(2), 155-163.

Ita, P. M., Attah, R. F., \& Nchor, E. E. Calabar metropolis, Cross River State, Nigeria". International Jou Key words.

Jonathan, T. Y. P., Moorthy, M. K., Annie, T., Choo, C., Chang, S.W. and Tan-Kah, L. (2012).A study on factors affecting the performance of small and medium enterprises in Malaysia. International Journal of Academic Research in Business and Social Sciences, 2(4)224 - 231.

Kateeb, M. (2009).The Extent unplanned Six Sigma using impact on Housing bankfor trade and finance. Unpublished Master Thesis, Middle East University.

Kogut, B., \& Zander, U. (1996). What firms do? Coordination, identity, and learning. Organization science, 7(5), 502518.

Krejcie, R. V., \& Morgan, D. W. (1970). Determining sample size for research activities. Educational and psychological measurement, 30(3), 607-610.

Kundi, O. H. K. (2005, November). A study of Six Sigma implementation and critical success factors. In Pakistan's 9th International Convention on Quality Improvement (pp. 1-12).

Kurniawati, E. Y., Santoso, B., \& Husnan, L. H. (2018). Budget Process of North Lombok Regency. International Research Journal of Management, IT and Social Sciences (IRJMIS), 5(2), 9-14.

Lee, K. L. (2003). Critical success factors of Six Sigma implementation and the impact on operations performance.

Maleka, N. A., Hove, G., \& Karodia, A. M. (2014). Assessing the Implementation of a Lean Six Sigma Improvement Programme: A Case Study of the Rail Engineering Organisation in Gauteng Province. Arabian Journal of Business and Management Review (Nigeria Chapter 2 (6): 25-70.

Mandahawi, N., Al-Shihabi, S., Abdallah, A. A., \& Alfarah, Y. M. (2010). Reducing waiting time at an emergency department using design for Six Sigma and discrete event simulation. International Journal of Six Sigma and Competitive Advantage, 6(1-2), 91-104.

Mbohwa, C., \& Madanhire, I. (2014). Use of six-sigma concept in discrete manufacturing industry. 6th Int'l Conference on Mechanical, Production \& Automobile Engineering ICMPAE'2014.

Moosa, K., \& Sajid, A. (2010). Critical analysis of Six Sigma implementation. Total Quality Management, 21(7), 745759.

Natarajan, R. N., \& Morse, J. (2009). Six Sigma in services-challenges and opportunities. International Journal of Productivity and Quality Management, 4(5-6), 658-675.

Okeke, T. C., Olise, M. C., \& Eze, G. A. (2012). Research Methods in Business and Management Sciences. Enugu, Iyke Venture Production.

Oko, A., \& Kang, P. S. (2015). Lean six sigma approach to improve the admissions process for a Nigerian HE Institute.

Okonkwo, V. O., \& Mbachu, V. M. (2015). A Comparative Analysis Of Application Of Six Sigma Project Management Technique In Small And Medium Scale Construction Companies In Nigeria. European Journal of Engineering and Technology, 3(3), 74-87.

Okoro, E. A., \& Washington, M. C. (2012). Workforce diversity and organizational communication: Analysis of human capital performance and productivity. Journal of Diversity Management (Online), 7(1), 57.

Okpala, K. E. (2012). Total quality management and SMPS performance effects in Nigeria: A Review of Six Sigma Methodology. Asian Journal of Finance \& Accounting, 4(2), 363-378.

Olawale, F., \& Garwe, D. (2010). Obstacles to the growth of new SMEs in South Africa: A principal component analysis approach. African journal of Business management, 4(5), 729-738.

Onwughalu, O. O., Okeke, K. E., \& Henry-Chibor, E. Lean production and its effect in organizations: A study of selected manufacturing firms in Nigeria.

Pasanen, M. (2010). Small and medium enterprise growth Strategies: A comparison of young and long-lived firms. Ph.D. Thesis, Unpublished. University of Kuopio, Kuopio.

Pokharkar, D., Jadhav, V., Gholve, S., \& Kadam, V. Development and validation of spectrophotometric method for estimation of prulifloxacin in tablet dosage form.

Radhakrishnan, R., \& Sivakumaran, P. K. (2010, January). Construction and Selection of Tightened-Normal-Tightened Schemes of Type TNT-(n1, n2; c) indexed through Six Sigma Quality Levels. In Proceedings of the 2010

Okafor, G., Agbaeze, E., Ekoja, G., \& Obamen, J. (2018). Effect of six sigma on performance of medium scale manufacturing firms in south-eastern Nigeria. International Research Journal of Management, IT and Social Sciences, 5(4), 26-45. https://doi.org/10.21744/irjmis.v5n4.253 
International Conference on Industrial Engineering and Operations Management (IEOM 2010), Dhaka, Bangladesh (pp. 9-10).

Reddy, G. P., \& Reddy, V. V. (2010). Process improvement using Six Sigma-a case study in small scale industry. International Journal of Six Sigma and Competitive Advantage, 6(1-2), 1-11.

Rinartha, K., \& Suryasa, W. (2017, August). Comparative study for better result on query suggestion of article searching with MySQL pattern matching and Jaccard similarity. In Cyber and IT Service Management (CITSM), 2017 5th International Conference on (pp. 1-4). IEEE.

Schroeder, R. G., Linderman, K., Liedtke, C., \& Choo, A. S. (2009). Six Sigma: Definition and underlying theory. Quality control and applied statistics, 54(5), 441-445.

Suleiman, A. S. Six Sigma and Business Environment in Nigeria.

Umude-Igbru, O., \& Price, B. (2015, March). Acceptability of Lean Six Sigma in a developing economy: Results from exploratory research in Nigerian consulting companies. In Industrial Engineering and Operations Management (IEOM), 2015 International Conference on (pp. 1-8). IEEE.

Varzandeh, J., \& Farahbod, K. (2010). Comparative and Strategic Role of ERP in "Six Sigma" Quality. Behavioral Sciences, 93.

Weinstein, L. (2010). A discussion of the suitability of Six Sigma techniques in non-profit arts and culture-oriented organisations. Asia Pacific Journal of Arts and Cultural Management, 7(1).

$\mathrm{Zu}$, X. (2005). A study of the impact of Six Sigma on firm performance: theoretical analysis and empirical investigation. 




Okafor, G., Agbaeze, E., Ekoja, G., \& Obamen, J. (2018). Effect of six sigma on performance of medium scale manufacturing firms in south-eastern Nigeria. International Research Journal of Management, IT and Social Sciences, 5(4), 26-45. https://doi.org/10.21744/irjmis.v5n4.253 